\title{
WACŁAW JĘDRZEJEWICZ JAKO ATTACHÉ WOJSKOWY I KIEROWNIK POLSKIEGO POSELSTWA W TOKIO W LATACH 1925-1928
}

\author{
Łukasz Czarnecki
}

Uniwersytet Jagielloński w Krakowie

\section{ABSTRACT \\ WACŁAW JĘDRZEJEWICZ AS A MILITARY ATTACHÉ AND HEAD OF THE POLISH LEGATION IN TOKYO (1925-1928)}

\begin{abstract}
Wacław Jędrzejewicz (1893-1993) was the longest surviving member of Józef Piłsudski’s closest entourage. During his lengthy life Jędrzejewicz served his fatherland in a wide variety of ways. The main focus of the article is the period between 1925 and 1928, when he served in Tokyo as the first Polish military attaché, subsequently becoming the head of the Polish legation in Japan, due to the vacancy for the position of deputy. During this time Jędrzejewicz actively worked towards establishing a closer relationship between Poland and Japan. Among his many initiatives was strengthening of the joint anti-USSR activity of the Polish and Japanese intelligence. He was also an attentive observer of Japanese politics and the accounts he sent to Poland remain a valuable resource for any researcher of Japanese interwar history.
\end{abstract}

Key words: Wacław Jędrzejewicz, interwar period, Polish-Japanese relations, Japan, Manchuria, China.

Słowa kluczowe: Wacław Jędrzejewicz, dwudziestolecie międzywojenne, stosunki polsko-japońskie, Japonia, Mandżuria, Chiny.

Wacław Jędrzejewicz był najbardziej długowieczną postacią obozu piłsudczykowskiego - jako jedyny człowiek z najbliższego otoczenia Józefa Piłsudskiego doczekał upadku komunizmu i powstania III RP. Ojczyźnie służył na wiele różnych sposobów: najpierw jako legionista, później biorąc udział w obronie Polski przed bolszewickim najazdem, następnie pracując w II Oddziale Sztabu Generalnego Wojska Polskiego, a po przejściu do cywila pełniąc rozmaite funkcje rządowe. 
Ich ukoronowaniem była nominacja w 1934 roku na ministra wyznań religijnych i oświecenia publicznego. Wreszcie na emigracji, pomimo odrzucenia jego usług przez gabinet generała Władysława Sikorskiego, aktywnie działał na rzecz popularyzacji sprawy polskiej, czego wyrazem było współzałożenie przez niego Instytutu Józefa Piłsudskiego w Nowym Jorku' ${ }^{1}$. W poniższym artykule chciałbym jednak skupić się na epizodzie z lat 1925-1928, kiedy to Jędrzejewicz pełnił w polskim poselstwie w Tokio funkcję attaché wojskowego, a następnie - w obliczu wakatu na stanowisku posła RP - także kierownika tejże placówki.

Już 19 września 1918 roku działający w Paryżu Komitet Narodowy Polski zwrócił się do rządu Japonii z prośbą o uznanie go za przedstawiciela polskich interesów na arenie międzynarodowej. Otrzymana od strony japońskiej odpowiedź nie była satysfakcjonująca - Japończycy woleli zachować dystans wobec polskich dążeń niepodległościowych ${ }^{2}$. Politykę tę kontynuowano także w pierwszych latach po powstaniu II RP, czego najdobitniejszym wyrazem był fakt, że japońskie poselstwo w Warszawie otwarto oficjalnie dopiero w roku 1921. Warto jednak zauważyć, że w przeciwieństwie do japońskiego MSZ Sztab Generalny wojska Kraju Kwitnącej Wiśni o wiele wcześniej zainteresował się nowo powstałymi państwami Europy Środkowo-Wschodniej. Było to związane z możliwością zainstalowania na ich terenach placówek wywiadowczych, obserwujących sytuację w europejskiej części Rosji. W związku z tym w roku 1919 nad Wisłą pojawił się specjalny wojskowy wysłannik (późniejszy pierwszy japoński attaché wojskowy w Polsce) kapitan Yamawaki Masataka³.

W trakcie swej bytności w Warszawie kapitan Yamawaki regularnie bywał w siedzibie II Oddziału Sztabu Generalnego Wojska Polskiego, gdzie wymieniał się z Polakami posiadanymi informacjami na temat Sowietów. W trakcie tych wizyt poznał szefa Wydziału Ewidencyjnego - majora Wacława Jędrzejewicza, z którym połączyła go prawdziwa przyjaźń. Gdy zatem minister spraw wojskowych - generał Władysław Sikorski rozpoczął czystkę, usuwając $\mathrm{z}$ wysokich stanowisk w wywiadzie wojskowym ludzi powiązanych z Józefem Piłsudskim, major Jędrzejewicz otrzymał przydział dyplomatyczny właśnie do Japonii. Na czas misji awansowano go na stopień podpułkownika. Warto w tym miejscu zaznaczyć, że do tej pory Rzeczpospolita nie miała na Wyspach swojego attaché wojskowego. Jędrzejewiczowi jako pierwszemu przedstawicielowi polskich sił zbrojnych przypadł zaszczyt pełnienia tej funkcji ${ }^{4}$.

${ }^{1}$ Na ten temat por. m.in.: R. S to b i e c k i, Wactaw Jędrzejewicz (1893-1993). Historyk epoki Józefa Pitsudskiego [w:] idem, Historycy polscy wobec wyzwań XX wieku, Poznań 2014, s. 127-167. Mimo roli odegranej na niwie wojskowości, polityki, dyplomacji i nauki Wacław Jędrzejewicz jak dotąd nie posiada swojej naukowej biografii.

2 E. P ała s z-R u t k o w s ka, The Making of an European Friend: Japan’s Recognition of Independent Poland [w:] The Decade of the Great War, red. T. Minohara, T.-K. Hon, E. Dawley, s. 231-256; E. P ała s z-R u tk ow sk a, A.T. R o m e r, Historia stosunków polsko-japońskich 1904-1945, Warszawa 2009, s. 77 i n.

${ }^{3}$ E. Pałasz-Rutkowska, A.T. Romer, op. cit., s. 82-84.

${ }^{4}$ W. Ję drzejewi c z, Wspomnienia, Wrocław 1993, s. 113-119. 
Wyjeżdżając na placówkę, podpułkownik zabrał ze sobą komplet specjalnie wyselekcjonowanych map i dokumentów dotyczących bolszewickiej Rosji. Zgodnie z ustaleniami, jakie poczynił przed wyjazdem ze swymi przełożonymi, w jego stosunkach ze stroną japońską - jeśli chodzi o zagadnienia rosyjskie - miała panować pełna otwartość. Wszelkie posiadane przez Polaków informacje na temat Sowietów miały być przekazywane Japończykom ${ }^{5}$.

Przed odmeldowaniem się Jędrzejewiczowi powierzono jeszcze jedną misję. Został mianowicie wezwany przed oblicze marszałka Józefa Piłsudskiego, który wówczas nie pełnił żadnych funkcji państwowych, wyjąwszy przewodniczenie Kapitule Orderu Virtuti Militari. Na trzydziestodwuletniego oficera czekała tu raczej zaskakująca wiadomość - marszałek zdecydował mianowicie o przyznaniu tego orderu 51 zasłużonym weteranom wojny japońsko-rosyjskiej z lat 1904-1905. Piłsudski, przez wiele lat studiując ten konflikt, doszedł bowiem do wniosku, że klęska caratu znacząco podniosła ducha mieszkających pod zaborem rosyjskim Polaków, a dokonywane przez armię Kraju Kwitnącej Wiśni manewry uznał za klasyczne i godne naśladowania przykłady sztuki wojennej ${ }^{6}$.

Załatwiwszy wszystkie sprawy związane z objęciem nowego stanowiska, Jędrzejewicz wyjechał z początkiem kwietnia do Paryża. Stamtąd udał się do Marsylii, gdzie wsiadł na statek płynący do Jokohamy. Po przeszło trzytygodniowej podróży, która nie obeszła się bez kilku przygód, podpułkownik dotarł do japońskiego portu, gdzie powitali go sekretarz polskiego poselstwa w Tokio Henryk Zaniewski oraz pracujący obecnie w japońskim Sztabie Generalnym, również noszący już rangę podpułkownika Yamawaki Masataka ${ }^{7}$.

W owym czasie przedstawicielstwo II Rzeczypospolitej w Japonii było placówką niezwykle skromną. Stanowisko posła sprawował od 1921 roku wybitny prawnik, znany obrońca członków PPS przed carskimi sądami i przelotny (1919-1920) minister spraw zagranicznych - Stanisław Patek ${ }^{8}$. Pracowali w nim także wspomniany już Henryk Zaniewski, dwaj urzędnicy kontraktowi: dr Eugeniusz Banasiński ${ }^{9}$, zajmujący się sprawami finansowymi i konsularnymi poselstwa, prowadzący kancelarię Jan Kobyliński, a także już nieoficjalnie opiekujący się Patkiem, który nie założył rodziny, służący mu pomocą we wszystkim Jan Czaja. Stanowisko attaché wojskowego powołano do życia w marcu 1925 roku, a realnie funkcjonować zaczęło ono

5 Ibidem, s. 120.

${ }^{6}$ Piłsudski, będący także historykiem wojskowości (czego dowodzą jego prace o powstaniu styczniowym) uważał się za znawcę wojny rosyjsko japońskiej 1904-1905 i posiadał pokaźny księgozbiór dotyczący tego konfliktu, łącznie z oficjalnym dziełem Cesarskiego Sztabu Generalnego (z tego ostatniego korzystać mógł, ze względów językowych, tylko z części zawierającej mapy). Por. W. Ję d r zej e wi c z, Józef Pitsudski 1867-1935. Życiorys, Londyn 1993, s. 116.

7 Ibidem, s. 123-126.

${ }^{8}$ Ostatnio naukową biografię Patka przedłożyła Małgorzata Gmurczyk-Wrońska, Stanisław Patek $w$ dyplomacji i polityce (1914-1939), Warszawa 2013; por. też eadem, Stanisław Patek - szkic do biografii, stan badań, źródła, problemy badawcze, „Dzieje Najnowsze” 2007, nr 2, s. 3-25.

9 Eugeniusz Banasiński (1886-1964) był m.in. autorem pionierskich w Polsce prac o Dalekim Wschodzie: Japonia współczesna. Sprawozdanie ekonomiczne, Warszawa 1927; Japonia-Mandżurja. Studium polityczno-ekonomiczne, Warszawa 1931. 
dopiero po przybyciu Jędrzejewicza do Japonii 26 maja 1925 roku. Zorganizowano je całkowicie na koszt Sztabu Generalnego, który zapewniał przedstawicielowi wojskowemu II Rzeczypospolitej skromne wyposażenie w wysokości 350 dolarów amerykańskich kwartalnie. Ciężar utrzymania finansowego stanowiska polski MSZ wziął na swe barki dopiero od roku 1926. Pieniądze przekazywane przez armię szybko okazały się niewystarczające, średnie wydatki miesięczne związane z funkcjonowaniem ataszatu wynosiły bowiem 150 dolarów ${ }^{10}$. Suma owa była wykorzystywana zarówno na wydatki reprezentacyjne, podróże, depesze do kraju, jak i na pracę wywiadowczą. Najbardziej kosztownym przedsięwzięciem podjętym przez Jędrzejewicza w przeciągu pierwszych miesięcy jego urzędowania była podróż do Mandżurii, gdzie zapoznał się z sytuacją polityczną panującą w tej chińskiej prowincji rządzonej przez marszałka Zhang Zuolina. Duże kwoty attaché wykorzystywać także musiał na cele reprezentacyjne, sprowadzające się do podtrzymywania poprawnych, a nawet serdecznych stosunków z oficerami japońskimi, z którymi współpracował. Przykładem może być tu wycieczka nad morze, zorganizowana przez niego dla szefa referatu polskiego i sowieckiego w japońskim Sztabie Głównym, znanego nam już podpułkownika Yamawaki. Z kolei poprzedniemu kierownikowi tegoż referatu, pełniącemu tę funkcję do listopada 1925 roku podpułkownikowi Komatsubarze Michitarō, Jędrzejewicz wręczył na pamiątkę współpracy srebrny kielich. Jako że pieniądze przesyłane $\mathrm{z}$ centrali nie wystarczały w pełni na pokrycie generowanych przez nie wydatków, attaché część kosztów pokrywał z własnej kieszeni ${ }^{11}$.

Jeszcze przed wyjazdem Jędrzejewicza do Japonii przełożeni polecili mu, aby udał się do Mandżurii, by zbadać tamtejsze stosunki polityczne. Było to niezwykle ważne zadanie, gdyż północna prowincja Chin graniczyła bezpośrednio z władztwem Sowietów, co więcej, zamieszkiwała ją znaczna liczba rosyjskich emigrantów, a także Polaków, którzy skupiali się głównie w Harbinie ${ }^{12}$. Ich liczebność szacowana jest bardzo różnie; harbiński Delegat RP Karol Pindor oznajmił w 1928 roku posłowi

${ }^{10}$ Czyli rocznie około 1800 dolarów. W tym samym czasie poseł USA w Chinach (a Jędrzejewicz pełnił wszak de facto - po wyjeździe Patka - także stanowisko posła - pobierał rocznie 10 tys. dolarów, zaś brytyjski 5 tys. funtów, co (przy kursie funta do dolara wynoszącym 4,86) składało się na niewyobrażalną w polskich warunkach kwotę ponad 24 tys. dolarów. W Japonii ambasadorowie mocarstw (w Chinach istniały tylko mniej prestiżowe poselstwa) zarabiali jeszcze więcej.

11 Jędrzejewicz do Wydziału Wywiadowczego Oddziału II Sztabu Generalnego, 2 II 1926, Archiwum Akt Nowych w Warszawie (dalej: AAN), zespół 616-689, Sztab Główny (dalej: Sz.G.), s. 8-11.

12 W. Ję drzejew i c z, Wspomnienia, s. 134-135. Na temat Polonii mandżurskiej, będącej częścią przybyszów z Imperium Rosyjskiego budujących na przełomie stuleci Kolej Wschodniochińską, istnieje już znaczna, choć różnej wartości, literatura. Poza trudno dostępnymi szkicami byłego konsula RP w Harbinie Konstantego Symonolewicza (Miraże mandżurskie, Warszawa 1931; fragmenty tej pracy opublikował niedawno rocznik „Azja-Pacyfik” (2014, nr 17, s. 9-24) pod tytułem Mała Polska na chińskiej ziemi) polecić można: M. Cabanow ski, Tajemnice Mandżurii. Polacy w Harbinie, Warszawa 1993; Polskie ślady na Dalekim Wschodzie. Polacy w Harbinie, red. A. F u rie r, Szczecin 2008; K i m Yong-D e o g, Kolonia polska w Mandżurii, 1897-1947, Kraków 2001; idem, Życie kulturalne Polaków w Mandzurii w latach 1897-1947, „Postscriptum Polonistyczne” 2010, nr 2 (6), s. 117-142; W. T h e is s, Dzieci syberyjskie. Dzieje dzieci polskich repatriowanych z Syberii i Mandzurii w latach 1919-1923, Warszawa 1992; B. Woj as, Dzieje Polonii Charbińskiej [sic!], „Zeszyty Historyczne” (Paryż) 1974, nr 30, s. 3-15. Barwna relacja bodaj ostatniego z żyjących członków tej społeczności: E. Kaj dańs ki, Wspomnienia z mojej Atlantydy, Kraków 2013. 
brytyjskiemu sir Milesowi Lampsonowi, że w Chinach „zdecydowana większość jego rodaków zamieszkuje Mandżurię. Jest ich tam trzy tysiące, podczas gdy w całej reszcie Chin jedynie stu, przy czym w zasadzie wszyscy w Szanghaju"'13. Domniemywać można, że jednym z celów podróży podpułkownika do położonej na północ od Wielkiego Muru krainy było zwerbowanie wśród ,białych” Rosjan agentów mogących służyć do szpiegowania bolszewików na Syberii. W swoich wspomnieniach wydanych w roku 1993 Jędrzejewicz pisze, iż odbył w Mandżurii szereg rozmów z przedstawicielami rosyjskich antykomunistycznych organizacji emigracyjnych ${ }^{14}$. Z kolei w skierowanym do Wydziału Wywiadowczego II Oddziału Sztabu Generalnego piśmie z dnia 2 lutego 1926 roku, w którym zdaje sprawę z poczynionych wydatków, podpułkownik wprost pisze, że będąc w tej prowincji i badając panujące w niej stosunki, stwierdził potrzebę założenia w Harbinie placówki wywiadowczej ${ }^{15}$.

Jędrzejewicz wyjechał do Mandżurii trzy miesiące po przyjeździe do Japonii w drugiej połowie sierpnia 1925 roku. W Harbinie spotkał się z tamtejszą Polonią. Należy tu wyjaśnić, że w owym czasie II Rzeczpospolita nie utrzymywała formalnych stosunków dyplomatycznych z Chinami, aczkolwiek uznały one de iure państwo polskie 27 marca $1920 \mathrm{roku}^{16}$. W Pekinie, gdzie rezydowali zagraniczni dyplomaci, nie było polskiego poselstwa. Ówczesna Republika Chińska z zasady najpierw zawierała z zagranicznym partnerem traktat, a potem dopiero uznawała jego przedstawiciela. Do czasu podpisania owego traktatu (do czego doszło dopiero w 1929 r.) teoretyczną opiekę nad interesami Rzeczypospolitej w Chinach sprawować miał poseł w Tokio Stanisław Patek, którego pełnomocnictwa jako posła także w Pekinie Naczelnik Państwa Józef Piłsudski i minister spraw zagranicznych Gabriel Narutowicz podpisali 20 października 1922 roku $^{17}$. Wizyta Patka w Pekinie, do której doszło wiosną 1922 roku, nie doprowadziła jednak do żadnych rozstrzygnięć, choć Chińczycy zgodzili się, aby na terenie Państwa Środka funkcjonowały polskie placówki podległe właśnie poselstwu w Tokio. Były to: ośrodek szanghajski, gdzie konsul Otto Hubicki rezydował wszakże „gościnnie” w konsulacie sprzymierzonej z Polską Francji ${ }^{18}$, pekiński, gdzie Michał Morgulec był p.o. konsula, zajmując

${ }_{13}$ Diariusz sir Milesa Lampsona [tzw. Killearn Diary], ST Anthony College, Middle East Archive, Oxford, zapis z 15 V 1928 (za udostępnienie tego dokumentu dziękuję dr. hab. Jakubowi Politowi). Trudność w oszacowaniu liczebności Polaków wynika z faktu, że większość z nich, będąc byłymi poddanymi rosyjskimi, nie posiadała paszportów RP.

${ }_{14}$ W. Ję drzejew i c z, Wspomnienia, s. 136.

15 Jędrzejewicz do Wydziału Wywiadowczego Oddziału II Sztabu Generalnego, 2 II 1926, AAN, zespół 616-689, Sz.G., s. 9.

${ }^{16}$ M. Nowak-Ki ełbikow a, Japonia i Chiny w dyplomacji II Rzeczypospolitej (próba zarysu), „Dzieje Najnowsze” 1981, R. XIII nr 1-2, s. 242. Pierwszy poseł chiński pojawił się w Warszawie dopiero w 1933 r. Ibidem, s. 243.

${ }^{17}$ S. Patek, Wspomnienia ważkich okresów pracy, Warszawa 1938, s. 22; M. Gmurczyk-Wrońska, Obraz Chin w raportach dyplomatycznych Stanistawa Patka z lat 20. XX wieku, „Azja-Pacyfik" 2013, t. XVI, s. 58.

18 X.Y.Z., Rozwój stosunków polsko-chińskich (1917-1936), Polityka Narodów” 1937, t. X, z. 3, s. 146-148. Szanghajska Koncesja francuska (Concession française) stanowiła de facto obszar eksterytorialny z władzami mianowanymi przez francuskiego konsula, a Pekin nie miał właściwie żadnej kontroli nad jej funkcjonowaniem. 
się głównie (jak Hubicki) sprawami repatriacji, oraz dominujący nad wszystkimi ośrodek mandżurski ${ }^{19}$. W lutym 1924 roku w Harbinie powstała Delegatura Rzeczypospolitej z Wydziałem Konsularnym, w związku z czym Stanisław Patek został zwolniony ze swoich chińskich obowiązków ${ }^{20}$. „Delegatem Pełnomocnym Rzeczypospolitej na Chiny" z tytułem (także) konsula został rezydujący w Harbinie wspomniany Karol Pindor, u boku którego wicekonsulem był znany orientalista i sinolog Konstanty Symonolewicz ${ }^{21}$.

W Harbinie działało wiele organizacji polonijnych, istniały polski kościół i gimnazjum, a także dwie, niestety skłócone z sobą drużyny harcerskie ${ }^{22}$. Do ich pogodzenia i stworzenia wspólnego hufca doszło dopiero wskutek interwencji podpułkowni$\mathrm{ka}^{23}$. Wkrótce po przyjeździe attaché do Mandżurii w budynku konsulatu wydano na jego cześć przyjęcie, na którym wygłosił on przemówienie o armii polskiej ${ }^{24}$.

Wyjazd Jędrzejewicza do ojczyzny rządzących do niedawna Chinami Mandżurów przyniósł wiele pozytywnych konsekwencji, takich jak zacieśnienie więzów miejscowej Polonii z macierzą czy pozyskanie od tamtejszych „białych” Rosjan licznych informacji, które potem podpułkownik wykorzystał w swoich sprawozdaniach $^{25}$. Stał się też, niestety, przyczyną konfliktu pomiędzy attaché a posłem Patkiem. Sporządziwszy i wysławszy do Warszawy raport poświęcony sytuacji politycznej panującej w położonej na północ od Wielkiego Muru krainie, podpułkownik zaprezentował go Patkowi. Ten, zapoznawszy się z jego treścią, zawrzał oburzeniem, stwierdziwszy, że zawarte w nim tezy są całkowicie sprzeczne z jego opiniami. Wzburzony poseł wysłał nawet do MSZ skargę na Jędrzejewicza. Ministerstwo nie podjęło jednak żadnych kroków przeciwko attaché26, a co więcej, w marcu 1926 roku to Patek został odwołany do kraju. Pojawił się jednak problem, Warszawa nie wyznaczyła bowiem żadnego następcy odchodzącego posła, powierzając kierownictwo poselstwem podpułkownikowi. Ten ostatni oprócz swego dotychczasowego

19 W. Skóra, Organizacja i pierwszy okres działalności polskich konsulatów w Harbinie $i$ Władywostoku $w$ latach 1920-1924 [w:] Polskie ślady na Dalekim Wschodzie, op. cit., s. 79-82, korzystałem z wersji elektronicznej http:/www.academia.edu/4174876/Wojciech_Sk\%C3\%B3ra Organizacja_i_pierwszy_okres_dzia\%C5\%82alno\%C5\%9Bci_polskich_konsulat $\%$ C3\%B3w_w_ Harbinie_i_W\%C5\%82adywostoku_w_latach_1920-1924_w_Polskie_\%C5\%9Blady_na_Dalekim_ Wschodzie._Polacy_w_Harbinie_red._A._Furier_Szczecin_2008_s._75-100 ; idem, Stużba konsularna Drugiej Rzeczypospolitej. Organizacja, kadry i działalność, Toruń 2006, s. 879.

20 W. Skóra, Organizacja i pierwszy okres działalności..., M. Gmurczyk-Wrońska, Obraz Chin.... s. 59.

${ }^{21}$ W. S kóra, Organizacja i pierwszy okres działalności..., s. 83-85. Symonolewicz, stały prezes rady opiekuńczej Polskiego Gimnazjum w Harbinie, po wyjeździe z Chin w 1930 r. był konsulem generalnym RP w Mińsku (1930-1932) i radcą poselstwa w Moskwie (1932-1933), potem zajął się publicystyką. Prócz wspomnianych już Miraży mandżurskich napisał też pracę wspomnieniową Moi Chińczycy (18 lat $w$ Chinach), Warszawa 1938.

${ }^{22} \mathrm{Na}$ ten temat por. R.K. D a s zki ew i c z, Harcerstwo polskie poza granicami kraju od zarania do 1930 r. w relacjach $i$ dokumentach, Lublin 1983, s. 175-181.

${ }_{23}$ Ibidem, s. 181; odpowiednie materiały znajdują się w: AAN, teczka 641, MSZ.

${ }^{24}$ W. Ję drzej ew i c z, Wspomnienia, s. 135-138.

${ }^{25}$ Niestety pomimo wytężonych poszukiwań przeprowadzonych w Archiwum Akt Nowych w Warszawie nie udało mi się ich odnaleźć.

${ }^{26}$ W. Ję drzejew ic z, Wspomnienia, s. 139. 
stanowiska miał pełnić teraz także funkcję chargé d'affaires. Miało to być rozwiązanie wyłącznie tymczasowe, ale gwałtowne zmiany polityczne w Polsce (przewrót majowy) sprawiły, że stan ów utrzymywać miał się przez następne dwa lata ${ }^{27}$. Oznaczało to dla Jędrzejewicza wiele nowych obowiązków, z których wywiązywał się wzorowo, zarówno reprezentując Rzeczpospolitą na oficjalnych uroczystościach, jak i śląc do MSZ regularne raporty czy załatwiając sprawy, z jakimi w poselstwie pojawiali się skądinąd nieliczni Polacy, których los rzucił na Daleki Wschód. Historie dwóch z nich wydają się dobrze ilustrować osobliwe nieraz przypadki rodaków, z jakimi zmagać się musiało przedstawicielstwo Rzeczypospolitej.

Jeszcze za kadencji Patka co jakiś czas pojawiał się w polskiej placówce dyplomatycznej, by odebrać przychodzące do niego na jej adres listy, niejaki Malewiczko. Był to osobnik nadzwyczaj barwny, wyjęty żywcem z powieści przygodowej, z którym również Jędrzejewicz miał przyjemność się poznać. Ówże Malewiczko, pochodzący z dawnego zaboru austriackiego (z okolic Rzeszowa), za młodu chcąc uniknąc służby wojskowej, zbiegł z kraju i udał się na tułaczkę po świecie. Początkowo los rzucił go do Ameryki Północnej, a dokładniej na Alaskę, gdzie poszukiwał złota. Na polu tym odniósł nawet ponoć pewne sukcesy, lecz zdobyte w ten sposób pieniądze szybko przepuścił. Niespokojny ten duch w poszukiwaniu nowego źródła zarobku zaczął kręcić się pomiędzy Stanami Zjednoczonymi a Dalekim Wschodem. Wszędzie miał znajomości, wszędzie robił interesy, ale, jak wyznał podpułkownikowi, skrycie marzył, by wrócić do Polski. W końcu zdecydował się przekuć marzenie w czyn i wyjechał do ojczyzny. Okazało się jednak, że poszukiwanie przygód zbyt weszło mu w krew i po pewnym czasie powrócił do Azji i znów stawił się w poselstwie. Na oku miał nowy biznes: polowanie na bobry na Hokkaido. Jak ten interes się skończył, tego Jędrzejewicz się nie dowiedział, gdyż po wyjeździe Malewiczki na ową północną wyspę już nigdy więcej go nie zobaczył.

Drugim ciekawym przypadkiem, z jakim los zetknął Jędrzejewicza, była sprawa pewnego polskiego hipnotyzera i magnetyzera, który przybył do Japonii z Malajów. Człowiek ten, jakoby znany na całym świecie magik, chciał zaprezentować swój kunszt przed Japończykami, jednakże cesarscy urzędnicy, powołując się na obowiązujący w Japonii zakaz prezentowania sztuk magicznych, zabronili mu zejścia na ląd. Podpułkownik interweniował w tej sprawie, dzięki czemu Polak mógł wraz $\mathrm{z}$ towarzyszącą mu małżonką opuścić pokład statku. O wystawieniu przedstawienia wciąż jednak nie mogło być mowy. Mimo to wdzięczny magnetyzer odwiedził polskie poselstwo, gdzie zaprezentował album zawierający wycinki prasowe dotyczące jego występów. Prócz tego okazało się, że niezwykły ów osobnik był podobnie jak Jędrzejewicz legionistą, w czasie I wojny światowej służącym jako ułan i znanym wśród kolegów z wojska pod pseudonimem „Magik”. Pomimo niewątpliwej sympatii, jaką u Jędrzejewicza wzbudził ten fakt, podpułkownik w swych wspomnieniach przyznał, że poczuł ulgę, gdy magnetyzer w końcu odpłynął z Japonii ${ }^{28}$.

Opisane przypadki, acz zapewne najbarwniejsze, nie były bynajmniej wyjątkowe. Przez Daleki Wschód przewijało się wiele nietypowych postaci narodowości

\footnotetext{
${ }^{27}$ Ibidem, s. 144.

${ }^{28}$ Ibidem, s. $150-152$.
} 
polskiej, przeważnie byłych poddanych rosyjskich, pomysłowych, ale popadających czasem w konflikt z miejscowym prawem. Ludzie ci odsiadki w chińskich i japońskich więzieniach przeplatali doraźnym podreperowaniem finansów na koszt zwykle wyrozumiałych placówek dyplomatycznych Rzeczypospolitej. Jak skarżyła się jedna $\mathrm{z}$ nich, ,przeto w końcu zachodzi coś w rodzaju perpetuum mobile, a w przerwach między wydaleniami delikwent zażywa wczasów w Harbinie" ${ }^{29}$.

Jędrzejewicz okazał się pilnym i wnikliwym obserwatorem japońskiej polityki. Świadczą o tym jego słane do Warszawy raporty, w których na bieżąco omawiał poczynania Japończyków zarówno na arenie międzynarodowej, jak i we własnym państwie. I tak, np. 1 czerwca 1926 roku donosił swym przełożonym o szeroko dyskutowanym w Kraju Kwitnącej Wiśni zagadnieniu nawiązania stosunków dyplomatycznych z krajami Bliskiego Wschodu. Nie omieszkał przy tym poinformować polskiego MSZ, że plany owe najprawdopodobniej mają na celu utworzenie na południe od ZSRR sieci działających pod przykrywką konsulatów placówek wywiadowczych mogących obserwować poczynania Sowietów na Bliskim Wschodzie. Przywoływał również opinię sowieckiego ambasadora Wiktora Koppa, który twierdził, że japońska akcja skierowana jest raczej przeciwko Anglikom i ma za zadanie szachowanie ich interesów w tym rejonie świata ${ }^{30}$. Stosunki sowiecko-brytyjskie były rzeczywiście coraz gorsze z powodu eskalacji rewolucji narodowej w Chinach, której doradcy sowieccy starali się (do czasu skutecznie) nadać antybrytyjskie ostrze: 26 maja 1927 roku Londyn miał zerwać stosunki dyplomatyczne z ZSRR. Liczono się z interwencją brytyjską w Chinach, co byłoby niemożliwe bez milczącego choćby poparcia Japonii ${ }^{31}$.

Trzy dni później, 4 czerwca, do ministra spraw zagranicznych wysłane zostało kolejne sprawozdanie, tym razem omawiające wizytę w Tokio zastępcy sowieckiego komisarza ludowego ds. komunikacji Leonida Sieriebriakowa, który - ku zaskoczeniu japońskich kół rządowych - pojawił się w ich stolicy 13 maja 1926 roku. Jędrzejewicz podejrzewał, że decyzję o przybyciu do Japonii Rosjanin podjął dopiero po fiasku dotyczących kolei wschodniochińskiej rozmów z kontrolującym Mandżurię marszałkiem Zhang Zuolinem. Trzeba przyznać, że ruch taki miałby duży sens wobec faktu, że mandżurski reżim marszałka znajdował się pod swoistym japońskim protektoratem.

Polski chargé d'affaires zwrócił uwagę na tajne rozmowy polityczne, jakie Sieriebrakow i ambasador Kopp odbyli z japońskim ministrem spraw zagranicznych baronem Shideharą Kijūrō. Z sobie tylko wiadomego, zbliżonego do MSZ źródła Jędrzejewicz dowiedział się, że w ich trakcie sowiecki komisarz zaproponował Japończykom podział wpływów w Mandżurii. Szef dyplomacji cesarskiej uciął jednak tego typu plany, stwierdzając, że żadne porozumienie dotyczące Chin nie może być omawiane bez udziału ich samych; ponieważ w realiach wojny domowej w Państwie Środka „udział Chin” oznaczał właśnie Zhang Zuolina, odmowa była ostateczna ${ }^{32}$.

${ }^{29}$ Raport administracyjny delegacji RP na Chiny w Harbinie za 1928, AAN, MSZ, 11739.

30 Jędrzejewicz do MSZ, 1 VI 1926, AAN, zespół 616-689, Sz.G., s. 18-19.

31 Na ten temat: J. Polit, Lew i smok. Wielka Brytania a kryzys chiński, 1925-1928, Kraków 2006.

32 Jędrzejewicz do MSZ, 4 VI 1926, AAN, zespół 616-689, Sz.G., s. 20-21; G. M c Corm a ck, Chang Tso-lin in Northeast China: China, Japan and the Manchurian Idea, 1911-1928, Dawson 1977, 
Pomimo nawału obowiązków związanych z pełnieniem funkcji chargé d'affaires nie zaniedbywał swych zobowiązań attaché wojskowego, informując II Oddział Sztabu Generalnego WP o wszystkich mogących go interesować zagadnieniach związanych z Japonią. Wkrótce po wizycie w Tokio Sieriebrakowa do władz wojskowych w Warszawie został wysłany raport omawiający panujące w społeczeństwie japońskim nastroje antyamerykańskie i zawierający prognozy dotyczące potencjalnego konfliktu Cesarstwa ze Stanami Zjednoczonymi. Zagadnienie to tylko z pozoru mogłoby się wydawać mało związane z polską racją stanu - podpułkownik w swej analizie słusznie zauważył bowiem, że jeśli Japończycy poważnie myśleli o stawieniu czoła Amerykanom, to życiową kwestią byłoby dla nich utrzymanie wpływów w stanowiącej zaplecze surowcowe Mandżurii. Tam jednak musieli się liczyć z konkurencją ZSRR. Skoro zaś ewentualny konflikt amerykańsko-japoński miałby zaangażować Sowietów, to jego sprawa powinna się znaleźć w kręgu zainteresowania Polski.

W swoim raporcie Jędrzejewicz przywołał artykuł Kawashimy Seijirō Pożądana wojna $z$ Ameryka opublikowany w anglojęzycznym magazynie „The Japan Advertiser", w którym autor omawiał potencjalny przebieg konfliktu pomiędzy obydwoma mocarstwami. Równocześnie informował o doniesieniach prasy amerykańskiej poświęconych rzekomemu japońskiemu planowi operacyjnemu z października 1925 roku, zakładającemu wykorzystanie przez Japonię w wypadku wybuchu wojny ze Stanami Zjednoczonymi Mandżurii i Korei jako baz zaopatrzeniowych. Sensacyjne te wiadomości zostały zdementowane przez szefa Oddziału Informacyjnego Sztabu Generalnego generała Matsui Iwane i szefa Wydziału Europejsko-Amerykańskiego tegoż sztabu pułkownika Tatekawę Yoshitsugu. Niemniej Jędrzejewicz podkreślał, że naczelne dowództwo armii japońskiej bardzo dobrze rozumiało wagę utrzymania dostaw surowców z Korei i Chin w wypadku wybuchu jakiejkolwiek wojny - czy to z USA, Wielką Brytanią, czy z ZSRR, surowców stanowiących dla Japończyków być albo nie być. Zwracał też uwagę na ewentualne możliwości polityczne, jakie otworzyłyby się przed Polską w wyniku konfliktu między Stanami Zjednoczonymi a Japonią, i doradzał zwierzchnikom dogłębniejsze ich zanalizowanie ${ }^{33}$.

Końcówka roku 1926 przyniosła Japończykom tradycyjnie przywiązanym do swej dynastii dotkliwy cios. Cesarz Taishō, od dawna już niezdrów, na krótko przed Bożym Narodzeniem zachorował ostatecznie i 25 grudnia zakończył życie ${ }^{34}$.

27 grudnia ciało zmarłego tennō zostało przywiezione do Tokio, gdzie oddali mu hołd przedstawiciele korpusu dyplomatycznego. Dyplomaci uzgodnili, że z okazji pogrzebu zakupią wspólnie jeden wykonany ze srebra wieniec, a prócz tego każda placówka złoży na grobie cesarza osobną wiązankę w imieniu swojego rządu.

s. 221-222; Ta o Shing - ch ang, International Controversies over the Chinese Eastern Railway, Taipei 1971 , s. 135.

33 Jędrzejewicz do Oddziału II Sztabu Generalnego, 15 VI 1926, ANN, zespół 616-689, Sz.G., s. $23-29$.

${ }^{34}$ T. Hara, Taishō, an Enigmatic Emperor and His Influential Wife [w:] The Emperors of Modern Japan, red. B.-A. S hillo ny, Leiden-Boston 2008, s. 234-235 (brak pełnej biografii cesarza w języku europejskim). 
Jędrzejewicz zdecydował, że polski wieniec również będzie srebrny, ale wysoka cena takowego sprawiła, że musiał wysłać do Warszawy prośbę o fundusze ${ }^{35}$.

Złożenie wieńców nastąpiło 4 lutego 1927 roku w specjalnie do tego przygotowanej sali pałacu cesarskiego. Trzy dni później rozpoczęły się właściwe uroczystości pogrzebowe. Zainaugurowało je prywatne nabożeństwo szintoistyczne, na którym obecni byli tylko przedstawiciele rodziny cesarskiej. Następnie zwłoki władcy umieszczono w żałobnym powozie, który o godzinie 18 wieczorem ruszył ulicami Tokio ku ogrodowi Shindjuku, gdzie nastąpiły kolejne obrzędy religijne. Tym razem brali już w nich udział przedstawiciele korpusu dyplomatycznego. Modły trwały między godziną 20 a 23, po ich zakończeniu pociąg przewiózł doczesne szczątki cesarza Taishō do stacji Asakawa. Gdy nadszedł świt, złożono je do specjalnego mauzoleum.

Pogrzeb imperatora zrobił na Jędrzejewiczu znaczne wrażenie. W swym raporcie do ministerstwa spraw zagranicznych podkreślał niezwykłą precyzję i wielki nakład czasu oraz pieniędzy, jakiego wymagało jego przygotowanie ${ }^{36}$. Był to niewątpliwy komplement dla ceremonialno-propagandowych umiejętności Japończyków.

10 lutego 1927 roku prezydent Stanów Zjednoczonych Calvin Coolidge wysuną propozycję zwołania w Genewie konferencji rozbrojeniowej mającej na celu kontynuację trendu zapoczątkowanego przez konferencję waszyngtońską, tj. zmniejszenie liczebności flot wojennych największych mocarstw ówczesnego świata. Państwem, które jako pierwsze zareagowało pozytywnie na ten pomysł, była Japonia, a przyczyny przychylności rządu japońskiego dla projektu Coolidge’a dogłębnej analizie poddał Jędrzejewicz w raporcie z dnia 16 marca 1927 roku skierowanym do polskiego ministra spraw zagranicznych.

W piśmie tym chargé d'affaires stwierdzał, że skwapliwość, z jaką Japończycy podchwycili pomysł amerykańskiego prezydenta, miała w pewnym stopniu podtekst propagandowy. W obliczu mieszania się tradycyjnego japońskiego wroga - czyli Związku Sowieckiego - w wewnętrzne walki toczone w Chinach, strona japońska zamierzała podkreślać swoją pokojowość w polityce prowadzonej względem pogrążonego w chaosie sąsiada. Inną ważną przyczyną, dla której Japonia poparła ideę konferencji, była według Jędrzejewicza chęć przekonania Amerykanów o wspólnocie interesów politycznych i ekonomicznych obydwu państw, co mogłoby skutkować zniesieniem uwierającego rząd japoński zakazu imigracji Japończyków do Ameryki.

Pobudki Kraju Kwitnącej Wiśni nie ograniczały się jednakże według autora raportu tylko do propagandy. Jako dobry obserwator japońskiej sytuacji politycznej i militarnej zauważył on, że olbrzymi budżet przeznaczany przez cesarski rząd na utrzymanie nadzwyczaj rozbudowanej machiny wojennej staje się dla Japonii coraz większym obciążeniem. Porównując ów dalekowschodni kraj do innych mocarstw, stwierdzał, iż Kraina Wschodzącego Słońca jest jedynym na ówczesną chwilę liczącym się w polityce światowej państwem, które równocześnie utrzymuje niezwykle liczną flotę i armię. Dla kontrastu przywołał przykład USA i Wielkiej Brytanii, które zredukowały swe wojska lądowe w zasadzie do minimum, poświęcając

\footnotetext{
35 Jędrzejewicz do MSZ, 31 XII 1926, AAN, zespół 592, MSZ, s. 10-12.

36 Jędrzejewicz do MSZ, 24 II 1927, AAN, zespół 592, MSZ, s. 1-4.
} 
całą energię rozbudowie floty mającej zabezpieczyć ich interesy na morzu, a także niektórych państw europejskich, w których występowała tendencja odwrotna, a flotylle wojenne służyły jako siła pomocnicza wobec armii. Japończycy tymczasem rokrocznie łożyli ogromne sumy na rozbudowę obu rodzajów broni. Propozycja częściowego rozbrojenia morskiego wielkich mocarstw trafiła zatem w Japonii na podatny grunt. Oznaczała bowiem pojawienie się nadziei na znaczne oszczędności. $\mathrm{Z}$ tego też powodu rząd japoński (oba sztaby generalne znacznie mniej) był żywo zainteresowany przeprowadzeniem demilitaryzacji, oczywiście o ile objęłaby ona także jej bezpośrednich sąsiadów, tj. ZSRR i Chiny, a także konkurentów do panowania na Pacyfiku, czyli Wielką Brytanię i USA.

Attaché zwrócił także uwagę na problem, z którym nieustannie borykała się japońska marynarka, mianowicie na będący jej piętą achillesową brak paliwa. Według podanych przez Jędrzejewicza danych roczne zapotrzebowanie Japonii na ropę naftową wynosiło około 850 tys. ton, z czego prawie połowę zużywała flota wojenna. Tymczasem produkcja własna Japonii wynosiła zaledwie 350 tys. ton, co oznaczało, że kraj uzależniony był od jej importu. Oznaczało to, że w wypadku wybuchu wojny bezpieczeństwo energetyczne Japonii i mobilność jej floty staną pod znakiem zapytania. Dlatego też w żywotnym interesie japońskiego rządu było odsunięcie widma ewentualnego konfliktu zbrojnego i ograniczenie rozmiarów marynarki ${ }^{37}$.

Kończąc ów wątek, stwierdzić należy, że trwająca od 20 czerwca do 4 sierpnia 1927 roku morska konferencja rozbrojeniowa w Genewie nie spełniła japońskich oczekiwań i zakończyła się fiaskiem, co spowodowane było między innymi niemożnością ustalenia wspólnego stanowiska delegacji brytyjskiej i amerykańskiej ${ }^{38}$.

Jednym z najważniejszych zagadnień nurtujących Japończyków w roku 1927 była kwestia chińskiej wojny domowej. Sprawa ta żywo dyskutowana w japońskich kręgach rządowych nie umknęła też uwadze Jędrzejewicza, mianowicie 19 lipca 1927 roku przesłał on do polskiego ministerstwa spraw zagranicznych raport poświęcony zorganizowanej przez japoński rząd premiera Tanaki Giichiego dziesięciodniowej konferencji poświęconej Chinom ${ }^{39}$. Obrady zgromadziły licznych specjalistów od Państwa Środka, zarówno cywilnych, jak i wojskowych. W trakcie konferencji starły się dwa poglądy - pierwszy reprezentowany przez wyższych rangą urzędników japońskiego MSZ, którzy forsowali zasadę nieingerencji w sprawy chińskie i załatwiania wszystkich zadrażnień drogą dyplomatyczną, i drugi, forsowany przez koła wojskowe. Zakładał on czynną obronę japońskich obywateli i interesów w Chinach, nie wykluczał też ewentualnego użycia przemocy. Ostatecznie zwyciężyli zwolennicy drugiego planu, czego wyrazem stała się ogłoszona po konferencji

37 Jędrzejewicz do MSZ, 1 III 1927, AAN, zespół 616-657, Sz.G., s. 257-260.

${ }^{38}$ W. Rojek, Spory o władanie morzem. Polityczno-dyplomatyczne aspekty zbrojeń morskich w okresie międzywojennym 1919-1939, Kraków 1994, s. 103-117; S. A s a d a, From Washington to London: The Imperial Japanese Navy and the Politics of Naval Limitations, 1921-1930 [w:] The Washington Conference 1921-1922, Naval Rivalry, East Asian Stability and the Road to Pearl Harbor, red. E. Goldste in, J. Maurer, London 1994, s. 162-169.

${ }^{39}$ Jędrzejewicz w swym raporcie podaje, że odbyła się ona pod koniec lipca, ponieważ jednak raport wysłany został w połowie tegoż miesiąca, chodzi o oczywisty błąd. Wiadomo skądinąd, iż Konferencja do Spraw Wschodu (Toho Kaigi) odbyła się w dniach od 27 czerwca do 7 lipca 1927 r. 
deklaracja premiera Tanaki, której Jędrzejewicz poświęcił w swoim raporcie dużo miejsca, co biorąc pod uwagę znaczenie owego dokumentu, jest w pełni zrozumiałe.

Rewolucyjną tezą postawioną przez rząd japoński we wzmiankowanej deklaracji było podzielenie Państwa Środka na trzy obszary: Chiny właściwe, Mandżurię i Mongolię, pociągające za sobą stwierdzenie o zróżnicowanej polityce wobec każdego z owych kompleksów. W Chinach właściwych Japończycy zamierzali zachowywać pozorną neutralność, utrzymując stosunki ze wszystkimi pretendującymi do kontroli nad nimi rządami, o ile te reprezentowałyby poglądy umiarkowane i nie zagrażały japońskim interesom. Jeśli chodzi o Mongolię i Mandżurię, to rząd japoński opowiadał się za utrzymaniem polityki otwartych drzwi, podkreślając przy tym jednak swoje specjalne interesy na terenie tych prowincji. Oddajmy zresztą głos samemu Jędrzejewiczowi, który tak oto podsumował ten dokument:

Z powyższego oświadczenia można wyciągnąć wnioski, iż Japonia chętnie widziałaby istnienie oddzielnych rządów w Chinach właściwych, Mongolji i Mandżurji, i, o ile rządy te nie sprzeciwiałyby się interesom japońskim, oddzielnie by je popierała. Zasada divide et impera została obecnie po raz pierwszy wyraźnie ujawniona, aczkolwiek właściwie istniała ona i dawniej zwłaszcza w stosunku do rządu Chang-tso-lina (Zhanga Zuolina) na terenie trzech wschodnich prowincyj ${ }^{40}$.

Jędrzejewicz zwracał uwagę także na fakt zwrotu w japońskiej polityce wobec Mongolii, którą przez ostatnie dwadzieścia lat Japończycy zbytnio się nie interesowali, a także na przebijającą ze słów deklaracji widoczną rezerwę, by nie rzec nawet wrogość, do wspieranych przez Sowietów sił Kuomintangu i sprzymierzonego z nim „,chrześcijańskiego generała” Feng Yuxianga. Analiza polskiego attaché dowodziła, że Japonia zamierzała uderzyć w sowieckie interesy na terenie Chin. Wyraził przypuszczenie, że zamiar ten został spowodowany przez znalezione nieco wcześniej w trakcie nalotu zorganizowanego przez ludzi Zhang Zuolina w sowieckiej ambasadzie w Pekinie dokumenty, z których jasno wynikało, iż Rosjanie prowadzą szeroką akcję mającą na celu oderwanie Mongolii od Chin i włączenie jej do ZSRR ${ }^{41}$.

Sam premier Tanaka, który objął swą funkcję 20 kwietnia 1927 roku, cieszył się wyraźną sympatią Jędrzejewicza, być może także z powodu żołnierskiej prezencji i rzadkiej u Japończyka osobistej wylewności (jako młody oficer zatrudniony w poselstwie w Rosji miał zwycięsko wyzywać gospodarzy na zawody, kto kogo przepije). Attaché oceniał, że nowy szef rządu ,odznacza się olbrzymią energią i wielkim zacięciem politycznym. $Z$ większych akcji przeprowadzonych przez niego wymienić należy interwencję japońską na Syberii w roku 1921 [oczywisty błąd maszynowy, powinno być

\footnotetext{
40 Jędrzejewicz do MSZ, 19 VII 1927, AAN, zespół 616-668, Sz.G., s. 9-12.

${ }^{41}$ Por. ibidem. Raport o wkroczeniu do ambasady sowieckiej w Pekinie wraz z fotokopiami dokumentów sporządzono w Warszawie latem 1927 r. Rewizja w ambasadzie sowieckiej w Pekinie - wnioski z otrzymanych dokumentów w Tokio. Do szefa sztabu generalnego, Warszawa dn. [brak daty dziennej] VIII 1927, AAN, zespół 616-682, Sz.G., s. 3 i n. Przekazanie przez stronę japońską fotokopii 68 przechwyconych dokumentów stanowiło szczególny gest i dowód zaufania wobec Warszawy.
} 
1920 - Ł.Cz.]"42. Pozytywnie wyrażał się o prowadzonej przez Tanakę polityce chińskiej, której owocem była między innymi dwukrotna, w 1927 i 1928 roku, interwencja zbrojna w prowincji Shandong, uważał ją bowiem za mającą ostrze antysowieckie. Nie krył jednak, iż polityka ta nie jest popularna w Japonii, wskazując, że „całość prasy występuje zgodnie przeciw wysłaniu wojsk"43.

Swoistym ukoronowaniem działalności podpułkownika Wacława Jędrzejewicza w Kraju Kwitnącej Wiśni była ceremonia odznaczenia 49 żyjących wciąż weteranów wojny japońsko-rosyjskiej z lat 1904-1905 orderami Virtuti Militari. Uroczystość ta odbyła się 28 marca 1928 roku w tokijskim hotelu Imperial, a jako goście honorowi brali w niej udział odznaczony już wcześniej najwyższym polskim orderem wojskowym marszałek Oku Yosutaka i sam premier Tanaka Giichi4 ${ }^{44}$

Atmosferę owego wydarzenia najlepiej przedstawić, oddając głos samemu attaché:

Gdy wszyscy się zebrali, Yamawaki ustawił ich w szereg, oddzielnie tych, którzy dostawali Virtuti Militari IV klasy. i oddzielnie odznaczonych V klasą: ordery były nadane według rang, jakie ci oficerowie posiadali wówczas, przed dwudziestu laty. Dziś stali przede mną starsi panowie, niektórzy w mundurach, inni w kimonach, inni w ubraniach europejskich. Z boku siedział marszałek Oku (stać nie mógł), a obok niego gen. Tanaka i inni.

Wygłosiłem po polsku bardzo krótkie przemówienie i wypowiedziałem formułę przepisaną regulaminem. Przetłumaczył to płk Yamawaki, po czym podchodziłem do każdego oficera, przypinałem mu krzyż i podawałem rękę. Potem winszowali im zaproszeni generałowie. [...]

Zapewne nie bardzo rozumieli, co Polska, która za czasów ich walk nie istniała na mapach Europy, miała wspólnego z wojną 1904-1905 roku. Wyjaśnienie tego było treścią mego przemówienia pod koniec obiadu, gdy piłem zdrowie odznaczonych. Tłomaczył jak zwykle niestrudzony Yamawaki. Odpowiedział mi premier Tanaka, wznosząc zdrowie Marszałka Piłsudskiego i pijąc za pomyślność Polski ${ }^{45}$.

W roku 1928 Warszawa w końcu wyznaczyła następcę Patka - został nim doświadczony dyplomata Zdzisław Okęcki, pełniący dotychczas funkcję posła polskiego w Belgradzie ${ }^{46}$. Nowy poseł przybył do Tokio 8 czerwca, a już pięć dni później został przyjęty na audiencji przez cesarza, któremu wręczył listy uwierzytelniające. W swoim pierwszym raporcie dla MSZ Okęcki meldował, że dzięki dobrym stosunkom, jakie z Japończykami utrzymywali Patek i Jędrzejewicz, został przyjęty przez gospodarzy niezwykle serdecznie ${ }^{47}$.

${ }^{42}$ [W. Jędrzejewicz], Kryzys gabinetowy w Japonji w kwietniu 1927, 27 IV 1927, AAN, zespół 616-657, Sz.G., s. 252.

43 Jędrzejewicz do MSZ, 24 IV 1928, AAN, zespół 616-668, Sz.G., s. 53-55.

${ }^{44}$ E. Pała sz-Rutkowska, A.T. Romer, op. cit., s. 138.

${ }^{45}$ W. Jędrzejewi cz, Wspomnienia, s. 166-167.

${ }^{46}$ Ibidem, s. 181-182.

47 Okęcki do MSZ, 16 VI 1928, AAN, zespół 600, MSZ, s. 66-67. 
Jesienią tego samego roku do Japonii przybył nowy attaché wojskowy, major Henryk Floyar-Rajchman. Dla Jędrzejewicza nastał czas powrotu do domu. Przed wyjazdem wraz ze swym następcą odbył szereg kurtuazyjnych wizyt u czołowych wojskowych i cywilnych dygnitarzy japońskich. W czasie obiadu u ministra wojny podpułkownik został odznaczony Orderem Świętego Skarbu. Floyar-Rajchman w przesłanym do szefa II Oddziału Sztabu Generalnego raporcie podkreślał niezwykły szacunek, jakim Jędrzejewicz był darzony przez Japończyków ${ }^{48}$. Wystawiato to na pewno dobrą opinię kwalifikacjom dyplomatycznym (oraz wojskowym) podpułkownika.

Jak ocenić trzy lata spędzone przez podpułkownika w Japonii? Czy była to tylko egzotyczna przygoda? Z opinią taką nie można się w żaden sposób zgodzić, choć wysyłając Jędrzejewicza na Daleki Wschód, generał Sikorski kierował się (zapewne) także chęcią zmarginalizowania go. Jednak ów plan się nie powiódł. Nawet na drugim końcu świata podpułkownik działał z niezwykłą wprost energią na rzecz sprawy polskiej. Przypuszczać można, że gdyby nie on, stosunki Polski z Japonią mogłyby nie stać się tak dobre, jakimi były w okresie dwudziestolecia oddzielającego obydwie wojny światowe. To jego mrówczej pracy na rzecz zacieśniania współpracy wojskowej pomiędzy narodem polskim i japońskim zawdzięczać możemy późniejszą współpracę wywiadowczą pomiędzy Rzecząpospolitą a Krajem Kwitnącej Wiśni. Jak powszechnie wiadomo, trwała ona również po 1939 roku, zniosła nawet atak na Pearl Harbor, wydarzenie, które postawiło obydwa państwa po przeciwnych stronach barykady ${ }^{49}$.

Biorąc pod uwagę powyższe, zaskakuje jednak, a nawet zdumiewa fakt, iż znawca polityki japońskiej, jakim bez wątpienia stał się Jędrzejewicz, jeśli chodzi o swe dalekowschodnie kwalifikacje, pozostał przez resztę życia niewykorzystaną kartą. Podczas pobytu w Kraju Kwitnącej Wiśni polski oficer nie tylko nawiązał bliskie kontakty, jeśli nie wręcz przyjaźnie, z osobami, których polityczna rola miała stale rosnąć (np. wspominany kilkakrotnie Yamawaki został wiceszefem sztabu generalnego), ale także opanował całkiem nieźle język swoich gospodarzy. Zważywszy, iż po swym powrocie Jędrzejewicz zastał kraj we władaniu bliskiej mu ekipy sanacyjnej, której tradycje współpracy z Tokio sięgały jeszcze lat 1904-1905, możliwości jego dalszej kariery na odcinku dalekowschodnim zdawały się rysować wręcz świetnie. Sam główny zainteresowany rozwiązania takiego sobie życzył, zwłaszcza gdy po 1935 roku jego akcje w ,zdekomponowanym” rządzącym obozie wyraźnie spadły. Nic podobnego jednak nie nastąpiło. Po złożeniu w październiku 1935 roku stanowiska ministra wyznań religijnych i oświecenia publicznego Wacław Jędrzejewicz piastował funkcję sekretarza generalnego Komitetu Krzyża i Medalu Niepodległości. W 1937 roku był prezesem Polskiego Komitetu Międzynarodowej Wystawy w Paryżu. Były to godności zaszczytne, ale nieadekwatne do jego kompetencji

${ }^{48}$ Floyar-Rajchman do Oddziału II Sztabu Generalnego, 12 X 1928, AAN, zespół 616-668, s. $177-178$.

${ }^{49} \mathrm{Na}$ ten temat piszą szeroko Ewa Pałasz-Rutkowska i Andrzej T. Romer (op. cit.), a także Andrzej Pepłoński i Hiroaki Kuromiya (Między Warszawa a Tokio. Polsko-japońska wspótpraca wywiadowcza 1904-1944, Toruń 2009). 
i w jakiejś mierze synekuralne. Do Kraju Kwitnącej Wiśni nie powrócił już nigdy. Trudno ustrzec się uwagi, iż jego umiejętności i kontakty japońskie w znacznym stopniu zostały przez II Rzeczpospolitą zmarnowane.

\section{BIBLIOGRAFIA}

\section{Archiwalia}

ST Anthony College, Middle East Archive, Oxford

Diariusz sir Milesa Lampsona [tzw. Killearn Diary]

Archiwum Akt Nowych, Warszawa

Zespół Ministerstwa Spraw Zagranicznych, MSZ

MSZ, 592 Poselstwo RP w Tokio. Zgon cesarza Japonii

MSZ, 600 Poselstwo RP w Tokio, korespondencja

MSZ, 7457 Poselstwo RP w Tokio

MSZ 11739 Delegacja RP na Chiny (Harbin)

Oddział II, Sztab Główny

Japonia 1921-1924, 1926-1928

616-665 Materiały dotyczące wojny domowej w Chinach

616-668 Japonia. Raporty attaché wojskowego RP

616-682 Rewizja w ambasadzie sowieckiej w Pekinie - wnioski z otrzymanych dokumentów w Tokio. Do szefa sztabu generalnego, Warszawa dn. [brak daty dziennej] VIII 1927

616-689 Japonia. Raporty attaché wojskowego RP

617-641 Korespondencja między attaché wojskowym w Tokio a Sztabem Głównym

\section{Pamiętniki}

Jędrzejewicz W., Wspomnienia, Wrocław 1993.

Kaj d ań s ki E., Wspomnienia z mojej Atlantydy, Kraków 2013.

Patek S., Wspomnienia ważkich okresów pracy, Warszawa 1938.

Sy monolewicz K., Moi Chińczycy (18 lat w Chinach), Warszawa 1938.

\section{Monografie, rozprawy, artykuły}

A s a da S., From Washington to London: The Imperial Japanese Navy and the Politics of Naval Limitations, 1921-1930 [w:] The Washington Conference 1921-1922, Naval Rivalry, East Asian Stability and the Road to Pearl Harbor, red. E. Gold st e in, J. Maure r, London 1994, s. 162-169.

B a n a sińs ki E., Japonia wspótczesna. Sprawozdanie ekonomiczne, Warszawa 1927. 
B a na siński E., Japonia-Mandżurja. Studium polityczno-ekonomiczne, Warszawa 1931.

Ca ba now ski M., Tajemnice Mandżurii. Polacy w Harbinie, Warszawa 1993.

$\mathrm{Ch}$ ib a I., Japanese-Russian Relations from the Formation of the Russo-Japanese Entente to to Siberian Intervention [w:] The Decade of the Great War. Japan and the Wider Word in the 1910s, red. T. M in o h ar a, T.-K. H o n, E. D a w le y, Leiden 2014, s. 114-149.

D a s z ki ew i c z R.K., Harcerstwo polskie poza granicami kraju od zarania do 1930 r. w relacjach i dokumentach, Lublin 1983.

D m o c h ow s k i A., Walka polityczna mocarstw o dominacje w dorzeczu Amuru, t. II: Interwencja mocarstw na Syberii i Dalekim Wschodzie, Warszawa 2009.

G murczyk - Wrońs k a M., Obraz Chin w raportach dyplomatycznych Stanisława Patka z lat 20. XX wieku, „Azja-Pacyfik” 2013, t. XVI, s. 57-68.

Gmurczyk-Wrońska M., Stanisław Patek - szkic do biografii, stan badań, źródła, problemy badawcze, „Dzieje Najnowsze” 2007, nr 2, s. 3-25.

Gmurczyk-Wrońska M., Stanisław Patek w dyplomacji i polityce (1914-1939), Warszawa 2013.

Hara T., Taishō, an Enigmatic Emperor and His Influential Wife [w:] The Emperors of Modern Japan, red. B.-A. S hill o n y, Leiden-Boston 2008, s. 234-235.

Japan and the Great War, red. O. Frat t o gli o, A. B e st, Folkestone 2015.

Ję drzej ew ic z W., Józef Pitsudski 1867-1935. Życiorys, Londyn 1993.

Ke i s h i O., The Siberian Intervention and Japanese Society [w:] Japan and the Great War, red. O. Fratt o gli o, A. B e st, Folkestone 2015, s. 96-115.

McCormack G., Chang Tso-lin in Northeast China. China, Japan and the Manchurian Idea, 1911-1928, Dawson 1977.

Modern Japan. Aspects of History, Literature and Society, red. W.G. B e a sley, London 1975.

Mort on W.F., Tanaka Giichi and Japan's China Policy, Folkestone 1980.

Nakat an i T., What Peace Meant to Japan. The Changeover at Paris in 1919 [w:] The Decade of the Great War: Japan and the Wider Word in the 1910s, red. T. Min ohara, T.-K. Ho n, E. D aw le y, Leiden 2014, s. 168-188.

$\mathrm{N}$ is h I., Japan and the Naval Aspects of the Washington Conference [w:] Modern Japan. Aspects of History, Literature and Society, red. W.G. B e s l le y, London 1975, s. 67-80.

Nowak-Ki ełbikowa M., Japonia i Chiny w dyplomacji II Rzeczypospolitej (próba zarysu), „Dzieje Najnowsze” 1981, R. XIII, nr 1-2, s. 240-253.

Pała sz-Rutk ow sk a E., Polityka Japonii wobec Polski 1918-1941, Warszawa 1998.

Pałasz-Rutkowska E., The Making of an European Friend: Japan's Recognition of Independent Poland [w:] The Decade of the Great War. Japan and the Wider Word in the 1910 s, red. T. Min o har a, T.-K. H o n, E. D a w le y, Leiden 2014, s. 231-256.

Pałasz-Rutkowska E., Romer A.T., Historia stosunków polsko-japońskich 19041945, Warszawa 2009.

Pepłoński A., Kuromiya H., Między Warszawa a Tokio. Polsko-japońska wspótpraca wywiadowcza 1904-1944, Torun 2009.

Polit J., Japonia, Anglosasi i interwencja na Syberii, 1918-1925, „Arcana” 1999, nr 26, s. $168-181$.

Polit J., Japońska polityka zagraniczna 1895-1945, Kraków 2015.

Polit J., Lew i smok. Wielka Brytania a kryzys chiński, 1925-1928, Kraków 2006.

Polit J., Odwrót znad Pacyfiku? Wielka Brytania wobec Dalekiego Wschodu 1914-1922, Kraków 1999.

Polskie ślady na Dalekim Wschodzie. Polacy w Harbinie, red. A. F u r i e r, Szczecin 2008. 
Roj e k W., Spory o władanie morzem. Polityczno-dyplomatyczne aspekty zbrojeń morskich w okresie międzywojennym 1919-1939, Kraków 1994.

Shing-chang Tao, International Controversies over the Chinese Eastern Railway, Taipei 1971.

Skóra W., Organizacja i pierwszy okres działalności polskich konsulatów w Harbinie i Wtadywostoku w latach 1920-1924 [w:] Polskie ślady na Dalekim Wschodzie. Polacy w Harbinie, red. A. F u r i e r, Szczecin 2008, s. 75-100.

S kór a W., Stużba konsularna Drugiej Rzeczypospolitej. Organizacja, kadry i działalność, Torun 2006.

Stobiecki R., Wacław Jędrzejewicz (1893-1993). Historyk epoki Józefa Pitsudskiego [w:] R. S to b i e c k i, Historycy polscy wobec wyzwań XX wieku, Poznań 2014, s. 127-167.

S y mo nol ew i c K., Mała Polska na chińskiej ziemi, „Azja-Pacyfik” 2014, nr 17, s. 9-24.

Symonolewic z K., Miraże mandżurskie, Warszawa 1931.

The Decade of the Great War. Japan and the Wider Word in the 1910s, red. T. Min o hara, T.-K. Ho n, E. D aw ley, Leiden 2014.

The Emperors of Modern Japan, red. B.-A. S hill o ny, Leiden-Boston 2008.

The Washington Conference 1921-1922. Naval Rivalry, East Asian Stability and the Road to Pearl Harbor, red. E. Gold st e in, J. Ma ure r, London 1994.

The is s W., Dzieci syberyjskie. Dzieje dzieci polskich repatriowanych z Syberii i Mandżurii w latach 1919-1923, Warszawa 1992.

Woj as B., Dzieje Polonii Charbińskiej [sic!], „Zeszyty Historyczne” (Paryż) 1974, nr 30, S. 3-15.

X.Y.Z., Rozwój stosunków polsko-chińskich. (1917-1936), Polityka Narodów” 1937, t. X, z. 3, s. $145-161$.

Yong-D e og Kim, Kolonia polska w Mandżurii, 1897-1947, Kraków 2001.

Yong-Deog Kim, Życie kulturalne Polaków w Mandżurii w latach 1897-1947, „Postscriptum Polonistyczne" 2010, nr 2 (6), s. 117-142. 